\title{
PENGANGKATAN ANAK DALAM PERSPEKTIF HUKUM ISLAM
}

\author{
Erha Saufan Hadana \\ saufanhadana@gmail.com
}

\begin{abstract}
This research was written with the background to find out how Islamic law responds to the issue of adoption, the rights obtained by adopted children and their position in inheritance. This research is a normative juridical research based on library data. The results of the study found that adoption in the perspective of Islamic law does not recognize adoption which makes it an absolute biological child, but the fulfillment of their rights such as clothing, food and education must still be fulfilled by adoptive parents. Regarding the position in inheritance, the child does not have the right to the inheritance of the adoptive parents, but may get a will not more than one third $(1 / 3)$ of the assets left behind.
\end{abstract}

Keywords: adoption of a child, islamic law

\begin{abstract}
Abstrak
Penelitian ini ditulis dengan latar belakang untuk mengetahui bagaimana hukum Islam merespon terhadap persoalan pengangkatan anak, hak-hak yang didapatkan oleh anak angkat serta kedudukannya dalam kewarisan. Penelitian ini merupakan penelitian yuridis normatif dengan bersumber pada data kepustakaan. Hasil penelitian ditemukan bahwa pengangkatan anak dalam perspektif hukum Islam tidak mengenal pengangkatan anak yang menjadikannya sebagai anak kandung mutlak, namun mengenai pemenuhuan hak-haknya seperti sandang, pangan, dan pendidikan tetap mesti dipenuhi oleh orang tua angkat. Prihal kedudukan dalam kewarisan, si anak tidak mempunyai hak terhadap harta waris orang tua angkat, namun boleh mendapatkan wasiat tidak lebih dari sepertiga (1/3) dari harta yang ditinggalkan.
\end{abstract}

Kata kunci: Pengangkatan, Anak, dan Hukum Islam 


\section{Pendahuluan}

Anak merupakan amanah yang berasal dari Tuhan Yang Maha Esa, sehingga seorang anak harus dijaga dan dilindungi harkat, martabat, dan akhlaknya sebagai manusia. Sebagian besar orang yang sudah berkeluarga tentu menginginkan untuk mendapatkan anak, (Rusli 2012: 9). Tetapi tidak semua pasangan suami isteri itu mempunyai anak dari rahim isteri sendiri, dimana kehendak mempunyai anak tidak tercapai. Manusia tidak akan puas dengan apa yang dialaminya, sehingga berbagai usaha dilakukan untuk memenuhi kepuasan tersebut. Pasangan suami istri memilih untuk mengangkat anak atau mengadopsi sebagai solusinya, (Muderis, 1992: 1).

Secara faktual bahwa pengangkatan anak telah menjadi bagian dari adat kebiasaan masyarakat muslim di Indonesia, dan telah merambah dalam praktek peradilan agama dengan dasar hukum undang-undang nomor 1 tahun 1974 tentang perkawinan dan Kompilasi Hukum Islam. Hal penting yang perlu digarisbawahi bahwa pengangkatan anak harus dilakukan dengan proses hukum dengan produk penetapan pengadilan. Sifat perbuatan pengangkatan anak merupakan perbuatan hukum yang tidak dapat dianggap hanya sebagai hasil dari kesepakatan antara dua pihak, pengangkatan anak harus harus melalui lembaga yang sah dan berwenang untuk menetapkan keputusan tersebut. Terjadinya pengangkatan anak seperti yang berlaku dalam tradisi barat dimana status anak berubah menjadi anak kandung, dan perbuatan tersebut dalam perspektif hukum Islam tidak dibenarkan. Seyogyanya pemberlakuan hukum Islam sebagai salah satu jalan untuk menjawab berbagai tantangan dan permasalahan yang dihadapi oleh umat muslim.

Pengangkatan anak adalah mengambil anak orang lain menjadikan anak sendiri. Pengangkatan anak harus dilakukan dengan proses hukum, yaitu dengan Penetapan Pengadilan. Permohonan pengangkatan anak diajukan kepada Pengadilan Negeri di tempat domisili anak yang akan diangkat tersebut. Adapun alasan permohonan diajukan adalah untuk kelangsungan hidup, kepentingan si anak, perkembangan fisik dan mental serta perlindungan anak itu sendiri. Untuk mengabulkan permohonan itu, hakim mengadakan penilaian tentang latar belakang alasan orang tua melepaskan anaknya, dan alasan calon orang tua angkat untuk mengangkat anak angkat tersebut, (Darwan 2003: 95).

Dalam Pasal 50 Undang-undang Nomor 49 Tahun 2009 Tentang Perubahan Kedua Atas Undang-undang Nomor 2 Tahun 1986 Tentang Peradilan Umum yang menyatakan: "Pengadilan Negeri bertugas dan berwenang memeriksa, memutus, dan menyelesaikan perkara pidana dan perdata di tingkat pertama" merupakan kewenangan Pengadilan Negeri untuk mengesahkan Pengangkatan Anak. Jadi, pada dasarnya semua kasus pidana maupun perdata merupakan kewenangan peradilan umum, kecuali ada ketentuan lain dalam Undang-undang yang menentukan bahwa terhadap perkara-perkara perdata tertentu menjadi kewenangan pengadilan dalam lingkungan peradilan lainm, (Ahmad 2010: 1). Termasuk permohonan untuk mendapatkan penetapan terhadap pengangkatan anak. 
Dalam peraturan perundang-undangan seperti Peraturan Pemerintah RI No. 54 Tahun 2007 Tentang Pelaksanaan Pengangkatan Anak terdapat syarat-syarat mengenai pengajuan penetapan pengangkatan anak di Pengadilan Negeri, seperti isi surat permohonan, syarat-syarat calon orang tua angkat, syarat anak yang akan diangkat serta surat-surat lain yang perlu dilengkapi.

Hakim dalam memutuskan setiap putusan atau penetapan harus memperhatikan segala aspek baik itu bersifat yuridis, sosiologis, dan filosofis, sehingga tercapainya suatu keadilan, diwujudkan, dan putusan hakim dapat dipertanggung jawabkan. Putusan hakim adalah putusan yang harus adil yang berdasarkan pada keadilan hukum (legal justice), keadilan masyarakat (social justice), dan keadilan moral (moral justice), (Lilik 2006: 121 ).

\section{Pengangkatan Anak dalam Hukum Islam}

Secara istilah menurut Wahbah al-Zuhaili pengertian Pengangkatan anak (tabanni) adalah Pengambilan anak yang jelas nasabnya yang dilakukan oleh seseorang, lalu anak tersebut di nasab-kan untuk dirinya. Dalam istilah lain, tabanni adalah seorang laki-laki maupun perempuan yang dengan berniat menasabkan seorang anak kepada dirinya walaupun anak tersebut sudah memiliki nasab yang jelas pada orangtua kandungnya. Pengangkatan anak dengan pengertian diatas sudah jelas bertentangan dengan hukum Islam, maka dari itu menasabkan seorang anak kepada orang lain yang bukan nasabnya harus dibatalkan, (Kamil, 2010: 95). Hal ini dapat dijelaskan dengan merujuk pada Al-Quran Surat Al-Ahzab ayat 4-5

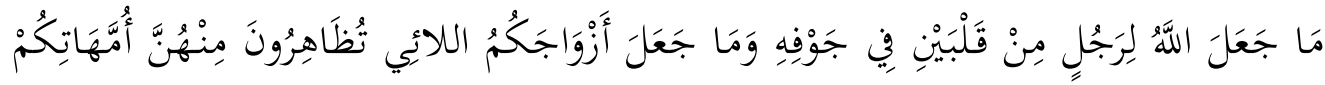

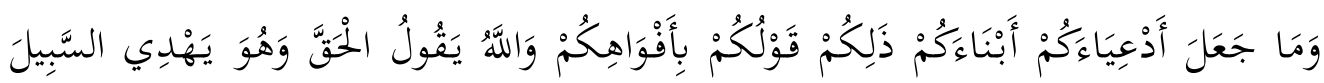

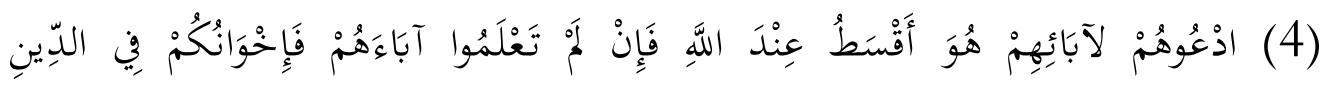

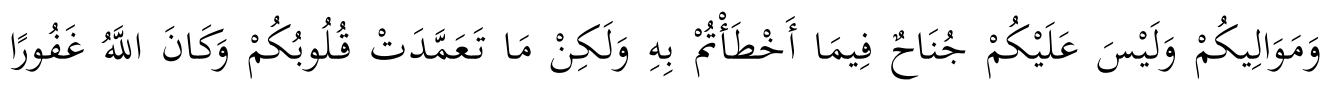

(5رحِيمًا (5)

Allah sekali-kali tidak menjadikan bagi seseorang dua buah hati dalam rongganya, dan Dia tidak menjadikan istri-istrimu yang kamu zihar itu sebagai ibumu, dan Dia tidak menjadikan anak-anak angkatmu sebagai anak kandungmu (sendiri). Yang demikian itu hanyalah perkataanmu di mulutmu saja. Dan Allah mengatakan yang sebenarnya dan Dia menunjukkan jalan(yang benar). 
Panggillah mereka (anak-anak angkat itu) dengan (memakai) nama bapak-bapak mereka; itulah yang lebih adil pada sisi Allah, dan jika kamu tidak mengetahui bapak-bapak mereka, maka (panggillah mereka sebagai) saudara-saudaramu seagama dan maulamaaulamu. Dan tidak ada dosa atasmu terhadap apa yang kamu khilaf padanya, tetapi (yang ada dosanya) apa yang disengaja oleh hatimu. Dan adalah Allah Maha Pengampun lagi Maha Penyayang. (QS Al-Ahzab ayat 4-5)

Jadi Pengangkatan anak dalam Hukum Islam terbatas pada perlakuan sebagai anak dari segi menyayangi, memelihara, memberikan nafkah, pendidikan dan segala kebutuhannya, bukan diperlakukan sebagai anak kandung sendiri, yang bertentangan dengan hukum Islam yaitu mengangkat (adopsi) anak dengan memberikan status yang sama kepada anak angkat dengan anak kandungnya.

Allah Swt menegaskan masalah anak angkat kepada Rasulullah Saw, beliau diperintahkan agar berpaling dari kaum musyrikin. Hal tersebut disampaikan setelah menyatakan bahwa Al-Qur'an adalah wahyu ilahi yang bersumber dari Allah Swt pemilik semesta alam, dan agar beliau konsisten, tidak meragukan wahyu Allah Swt. Bertakwalah kepada Allah Swt tidak patuh kepada kaum kafir dan munafik, serta mengikuti secara sungguh-sungguh wahyu dari Allah Swt. Kemudian Allah Swt menurunkan hukum yang tegas tentang anak angkat yang sudah dikenal dikalangan Arab Jahiliyah, dengan sebutan "al-tabanni". At-tabani sama dengan adopsi, dan anak yang diadopsi diperlakukan persis sama dengan anak kandung, (Kamil, 2010: 153).

Pengangkatan (adopsi) anak menurut hukum Islam hanya dapat dilakukan apabila memenuhi kebutuhan sebagai berikut: Pertama, Tidak memutuskan hubungan darah dengan anak diangkat terhadap orang tua kandung dan keluarga, dari ketentuan ini jelas melarang untuk mengangkat anak dengan maksud menjadikan anak kandung dalam segala hal yang akan menghilangkan atau memutuskan hubungan atau kedudukan hak orag tua kandung dan dapat merombak ketentuan mengenai waris. Kedua, Anak angkat tidak mendapatkan warisan dari orang tua angkatnya, sebaliknya tetap sebagai pewaris orang tua kandungnya, lalu orang tua angkat tidak berhak sebagai pewaris dari anak angkatnya. Ketiga, Anak angkat tidak berhak menggunakan nama orang tua angkatnya kecuali sekedar tanda pengenal/alamat. Keempat, Orang tua angkat tidak bisa bertindask sebagai Wali dalam Pernikahan anak angkatnya, (Habiburrahman, 2011: 157).

Dari ketentuan di atas dapat diketahui bahwa pengangkatan anak (adopsi) dalam hukum Islam bersifat memelihara anak dengan tujuan agar anak tersebut tidak terlantar dalam pertumbuhan dan perkembangannya. 
Pengasuhan anak ditujukan terhadap orang tuanya anak yang tidak mampu atau tidak dapat menjamin terselenggaranya hak-hak anak baik fisik, spiritual, mental maupun sosialnya. Maka, pengasuhan tersebut termasuk, pemeliharaan anak, mendidik anak, mencerdaskan pikirannya dan mengarahkan bakatnya untuk mempelajari keterampilan, hingga dewasa atau mampu berdiri sendiri. Berdasarkan Kompilasi Hukum Islam di Indonesia (Inpres No.1 tahun 1991) pasal 156 huruf (a) dikatakan kalau terjadi perceraian, bahwa untuk anak yang belum mumayyiz, hak hadhanah adalah kepada ibu. Dan kalau ibu telah meninggal dunia, maka beralik kepada, (Sayyid Sabiq 2007: 140):

a. Wanita-wanita dalam garis lurus ke atas dari ibu

b. Ayah

c. Wanita-wanita dalam garis lurus ke atas dari ayah

d. Saudara perempuan dari anak yang bersangkutan

e. Wanita-wanita kerabat sedarah menurut garis samping dari ibu

f. Wanita-wanita kerabat sedara menurut garis samping

Sedangkan pada (Inpres No.1 tahun 1991) pasal 156 huruf (b) dikatakan bahwa anak yang sudah mumayyiz berhak memilih untuk mendapatkan hadhanah dari ayah atau ibu. Berdasarkan Kompilasi Hukum Islam di Indonesia (Inpres No.1 tahun 1991) pasal 156 huruf (d) menyatakan bahwa biaya hadhanah adalah sekurang-kurangnya sampai anak tersebut dapat mengurus diri sendiri (21 tahun).

Pengangkatan anak berdasarkan hukum Islam, berbeda dengan Adopsi menurut Hukum Perdata. Karena menurut Hukum Islam adalah:

a. Tidak merubah status anak tersebut dengan orang tua aslinya

b. Tidak Melepaskan hak dan kewajiban orang tua aslinya terhadap anak tersebut

c. Tidak memutuskan hubungan saling mewarisi dengan orang tua aslinya dan dengan kerabat yang lainnya ;

d. Tidak menjadikan saling mewarisi dengan orang tua angkatnya. Namun hanya mendapat wasiat wajibah, yang nilainya tidak melebihi $1 / 3$ dari harta

e. Status muhrim dalam agama, tetap sebagai orang lain, sehingga kalau orang anak angkat tersebut perempuan, maka ia tidak boleh hanya berdua dalam rumah (khalwat), (Sayyid Sabiq 2007: 140).

Oleh karena itu, anak angkat dalam Islam, tidak lebih sebagai hak hadhanah dan dapat sebagai kuasa/wali dalam bertindak hukum untuk anak yang belum dewasa. Bila terjadi sengketa terhadap hadhanah, maka anak tidak dapat disamakan dengan hukum kebendaan yang dapat di eksekusi . Hal ini, dalam rangka merespon perlindungan terhadap hak-hak 
anak. Sedangkan Pengangkatan anak dalam pengertian yang terbatas, kedudukan hanya diperbolehkan bahkan dianjurkan. Pengangkatan anak yang diutamakan adalah memperlakuan anak sebagai anak dalam segi menyayangi, memelihara, pemberian nafkah, pendidikan, dan segala kebutuhannya, tidak diperlakukan sebagai anak kandungnya sendiri, (Alimudin 2015: 18).

\section{Kedudukan Anak Angkat Menurut Hukum Islam.}

Dalam karangan ulama Yusuf Qardhawi, di dalam bukunya Halal dan Haram dalam Islam menguraikan secara singkat perihal pengangkatan anak menurut Islam. Ulama tersebut kelahiran Mesir tahun 1926 yang sejak tahun 1961 tinggal Doha Qatar. Adat istiadat di Zaman jahiliyah ada seseorang dibolehkan mengasuh anak orang lain untuk dijadikan sebagai anak kandungnya sendiri, dan juga bisa memakai nama orang tua angkatnya, dan anak angkat juga mendapatkan warisan dari orang tua angkatnya, jadi itulah yang diharamkan dalam Islam.

Dalam buku Amir Syarifuddin "Hukum Kewarisan Islam" mengatakan bahwa dalam Islam tidak mengenal yang namanya anak angkat atau dikenal dengan Pengangkatan Anak yang artinya terlepas anak angkat dari keluarga orang tua kandungnya dan berpindah ke dalam keluarga orang tua angkatnya.

Rasulullah Saw pernah mengalami hal tersebut dengan mengadopsi Zaid bin Haritsah seorang hamba sahaya yang dihibahkan kepada isterinya Khadijah oleh Rasulullah Saw untuk mengasuhnya. Kemudian terlalu sayangnya beliau mengangkat Zaid menjadi anaknya sendiri, hingga orang banyak memanggil anak angkat itu menjadi Zaid bin Muhammad. Hadist Bukhari Muslim, Tarmizi dan Nasai, dari Ibnu Umar radhiallahu'anhu mengatakan " Tidaklah kami memanggil Zaid bin Harisah melainkan dengan panggilan Zaid bin Muhammad".

Hal ini dapat dijelaskan dalam Al-Qur'an surat Al-Ahzab ayat 37

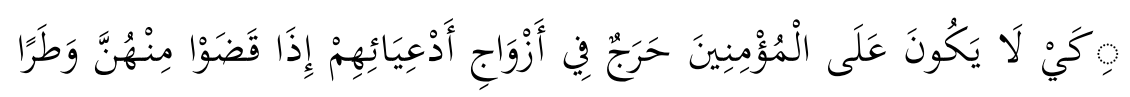

Supaya tidak ada keberatan bagi orang mukmin untuk (mengawini) istri-istri anak-anak angkat mereka, apabila anak-anak angkat itu telah menyelesaikan keperluannya dari istrinya. (Al-Ahzab: 37)

Mengangkat anak yatim tujuannya utamanya untuk memelihara dan mendidik tanpa menasabkan pada dirinya, maka itu adalah sifat dipuji oleh Allah Swt. Ulama kontemporer seperti Yusuf al-Qaradlawi berpandangan bahwa mengangkat anak dan menisbatkan nasab kepada 
bapak angkat adalah haram. Apabila pembagian warisan terhadap anak sediri disamakan dengan anak angkat. Mengasuh anak orang lain atau anak yatim itu perbuatan mulia, lalu menjadikan anak angkat sebagai ahli waris adalah suatu hal yang bertentangan dengan ketentuan nash. Seluruh ulama mengatakan dibolehkan mengangkat anak sebatas memelihara, mengasuh dan pendidikan, bukan untuk memberikan status seperti layaknya anak kandung. Berdasarkan hal tersebut, kalangan ulama mazhab mengajukan solusi untuk memberikan harta waris terhadap anak angkat melalui wasiat wajibah, (Habiburrahman, 2011: 157).

Undang-undang wasiat Wajibah Nomor 71 tahun 1356 H/ 1946 M, di Mesir telah dikeluarkan. Undang-undang ini mengandung hukumhukum sebagai berikut:

a. Apabila pewaris tidak mewasiatkan kepada keturunan anak lakilaki yang telah meninggal lebih dulu maka cucu dari anak lakilaki tersebut wajib mendapat wasiat wajibah dari harta warisan pewaris sebanyak bagian anak laki-laki pewaris tersebut, tetapi tidak boleh melebihi $1 / 3$ harta warisan, dengan syarat cucu tersebut bukan ahli waris dan belum ada bagian untuknya melalui jalan lain (hibah).

b. Wasiat diberikan kepada golongan tingkat pertama dari anak laki-laki, dari anak perempuan, dan kepada anak laki-laki dari anak laki-laki dari garis laki-laki dan seterusnya kebawah dengan syarat kedua orang tua meng hijab anaknya.

c. Apabila pewaris mewasiatkan kepada orang yang wajib dengan wasiat yang melebihi bagianya, maka kelebihan wasiat itu merupakan wasiat ikhtiyarah. Dan bila dia mewasiatkan kepadanya dengan wasiat yang kurang dari bagiannya, maka wajib disempurnakannya.

d. Wasiat wajibah itu di dahulukan atas wasiat-wasiat yang lain. Bila pewaris mewasiatkan kepada orang lain dan tidak mewasiatkan kepada orang yang diwasiati maka orang yang wajib mendapatkan wasiat wajibah tersebut adalah mengambil dari kadar bagian dari sisa $1 / 3$ harta warisan bila sisa itu cukup dan bila tidak bagian yang diwasiatkan bukan Wasiat Wajibah, (Habiburrahman, 2011: 157).

Adapun ketentuan pasal $209 \mathrm{KHI}$, sesuai dengan teori mashlahah al-ummah, maka anak angkat dapat bagian dari wasiat wajibah dengan harta warisan dengan rekontruksi pemikiran sebagai berikut:

a. Bahwa dalam Islam, anak angkat di bolehkan hanya sebatas memelihara, pendidikan, pengayoman dan dilarang memberi status layaknya anak kandung sendiri. Kalimat ini hendaklah 
dimuat dalam pertimbangan hukum, setiap putusan/penetapan pengangkatan anak oleh Pengadilan Agama.

b. Bahwa orang tua angkat dapat memberikan hartanya kepada anak angkat berdasarkan wasiat yang tidak boleh melebihi 1/3 harta orang tua angkatnya yang telah meninggal.

c. Bahwa bila ada sengketa dengan status anak angkat maka harus disidangkan oleh putusan Pengadilan.

d. Bahwa bila ada sengketa tentang wasiat wajibah bagi anak angkat, maka harus diputuskan dipengadilan yang mengatakan: anak angkat berhak atau tidak atas wasiat wajibah dalam praktik kumulasi dalam sengketa kewarisan, tetapi petitum khusus untuk menyatakan berhak mendapatkan wasiat wajibah tidak ada, karena ketentuan dalam KHI bersifat imperatif, harusnya bersyarat kepada nash Al-Qur'an yang mengisyaratkan bagi pewaris meninggal dunia, (Sayyid Sabiq 2007: 983).

Ulama fikih mengemukakan beberapa persyaratan terhadap harta yang di wasiatkan yaitu: pertama, harta/benda yang diwasiatkan adalah sesuatu yang bernilai harta secara syara' (al-mutaqawimah). Oleh karena itu, apabila harta yang diwasiatkan itu tidak bernilai harta menurut syara', seperti minuman keras, maka wasiatnya tidak sah. Secara lahirnya minuman keras merupakan harta, tetapi umat Islam harta tersebut bukan harta yang halal sehingga tidak bisa dijadikan sebagai harta wasiat.

Kedua, harta yang diwasiatkan adalah harta yang sesuatu yang bisa dijadikan milik, baik berupa materi maupun manfaat. Misalnya, mewasiatkan sebidang tanah, atau mewasiatkan pemanfaatan lahan pertanian. Ulama fikih membolehkan mewasiatkan sesuatu yang ada, sekali pun akad yang di buat materi yang akan diwasiatkan itu belum ada. Misalanya, mewasiatkan buah-buahan dari sebidang kebun. Ketika wasiat dibuat, pohon itu baru berputik. Apabila pemilik kebun berwasiat, "ketika saya wafat buah-buahan dikebun ini saya wasiatkan kepada si fulan," maka wasiatnya sah. Ketiga, harta yang diwasiatkan adalah milik almusi, ketika berlangsungnya wasiat. Keempat, sesuatu yang diwasiatkan tidak mengandung unsur maksiat, (Kamil, 2010: 136).

Adapun syarat-syarat yang berkaitan dengan shighat, pada dasarnya shighat wasiat hanya disyaratkan berupa suatu perkataan atau lafads yang jelas yang menunjukan pada pengertian pemberian wasiat untuk seseorang atau lebih, baik secara lisan maupun tulisan. Disamping itu, dapat juga disampaikan secara terang-terangan maupun secara sindiran asalkan sudah menunjukan pada pengertian wasiat. Wahbah ALZuhaili menegaskan bahwa mayoritas ulama sepakat bahwa wasiat baru sah menggunakan ijab dan qabul, dan boleh juga menggunakan bahasa isyarat dan tulisan diantaranya: pertama, ulama fikih menetapkan bahwa 
shighat ijab dan Kabul yang digunakan dalam wasiat harus jelas, dan qabul dan ijab harus sejalan. Misalnya, apabila apabila ada seseorang dalam ijabnya menyatakan "saya wasiatkan kepada engkau $1 / 3$ harta saya," maka qabul orang yang menerima wasiat itu harus sejalan.

Kedua ucapan qabul yang diberi wasiat ketika orang yang berwasiat masih hidup, tidak berlaku. Akan tetapi, menurut ulama Mazhab Hanafi, qabul bolh diucapkan sebelum atau sesudah orang yang berwasiat wafat. Ulama juga sepakat bahwa apabila seseorang telah berwasiat kepada fulan, lalu fulan wafat setelah al-musi wafat tetapi belum menyatakan qabulnya, maka ucapan qabul digantikan oleh ahli waris fulan. Ketiga, qabul harus diungkapkan oleh orang yang telah baligh dan berakal. Apabila penerima wasiat adalah anak kecil atau orang gila, maka qabul meski diwakili oleh walinya. Keempat, ulama fikih sepakat tidak mensyaratkan qabul, apabila wasiat ditujukan untuk kepentiangan umum, seperti untuk mesjid, anakanak yatim, yang identitasnya tidak dijelaskan dalam wasiat.

Kelima, wasiat diperbolehkan melalui isyarat yang dipahami, menurut Mazhab Hanafi dan Mazhab Hambali ketentuan ini hanya bisa diterima apabila pewasiat tersebut bisu dan tidak bisa membaca dan menulis maka isyarat tidak sah. Sebaliknya, menurut ulama Mazhab Syafi'i dan Mazhab Maliki berpendapat bahwa wasiat tersebut tetap sah karena isyarat tersebut dapat dipahami oleh pewasiat meskipun mampu berbicara dan baca tulis. Keenam, qabul menurut jumhur ulama, harus diungkapkan melalui lisan atau tindakan hukum yang menunjukan kerelaan penerima wasiat tersebut, seperti bertindak hukum pada barang yang diwasiatkan, (Kamil, 2010: 137).

\section{Akibat Hukum Anak Angkat Menurut Hukum Islam.}

Menurut Wahbah az-Zuhaili ada lima macam hak anak terhadap orang tuanya, yaitu hak nasab, hak radla, hak hadhanah, hak walayah dan hak nafkah. Hak-hak tersebut akan dijelaskan sebagai berikut: pertama, hak nasab adalah sebuah pengakuan sya'ra bagi hubungan seorang anak dengan garis keturunan ayahnya sehingga dengan itu anak tersebut menjadi salah seorang anggota keluarga dengan garis mendasar. Kedua, hak radla' menurut adalah hak anak mendapatkan pelayanan makanan pokok dengan jalan menyusu pada ibunya. Ibu bertanggung jawab dihadapan Allah tentang hal, baik masih dalam tali perkawinan dengan anak si bayi atau sudah di talak dan sudah habis masa iddahnya.

Ketiga, hak hadhanah menurut bahasa adalah meletakkan sesuatu dekat tulang rusuk seperti mengengdong, atau meletakkan sesuatu dalam pangkuan. Menurut fiqh, hadhanah ialah tugas menjaga dan mengasuh atau mendidik bayi atau anak kecil sejak ia lahir sampai mampu menjaga 
atau mengatur diri sendiri. Keempat, hak walayah yakni untuk meyambung dan menyempurnakan pendidikan anak sampai baligh, pemeliharaan harta dan mengatur pembelajaan harta anak kecil dan perwalian dalam pernikahan bagi anak perempuan. Kelima, hak nafkah yakni pertanggungjawaban orang tua atau kerabat terdekat atas nafkah anak.

Pengangkatan anak dalam Islam sama sekali tidak merubah hubungan hukum, nasab dan mahram antara anak angkat dengan orang tua dan keluarga asalnya. Pangangkatan anak dalam Islam ini tidak merubah status anak angkat menjadi anak kandung dan status orang tua angkat menjadi orang tua kandung, yang dapat saling mewarisi seperti anak kandung sendiri. Hanya saja adanya perpindahan tanggung jawab pemeliharaan, pengawasan, dan pendidikan.

Sayyid Sabiq, menyatakan bahwa merawat anak yang terlantar tanpa memutuskan nasab orang tua kandungnya merupakan wajib hukumnya karena masyarakat bertanggung jawab dalam melaksanakan kewajiban kifayah, tetapi hukum tersebut bisa berubah menjadi fardlu'ain apabila seseorang menemukan anak terbuang di tempat yang membahayakan nyawa anak tersebut, dan anak tersebut akan ditetapkan ke Islamanya apabila dia ditemukan di negeri kaum muslimin dan barang siapa yang mengakui nasab anak tersebut, baik dia laki-laki maupun perempuan, maka anak tersebut dinisbatkan kepadanya, selagai keberadaan anak itu memungkinkan karena didalamnya terdapat maslahat anak tersebut tanpa merugikan orang lain. Apabila anak itu diakui lebih dari satu orang maka nasabnya ditetapkan bagi orang yang menunjukan bukti atas pengakuanya, apabila mereka menunjukan bukti maka anak dihadapkan kepada ahli nasab yang mengetahui nasab manusia melalui keserupaan, dan ketika ahli nasab telah menetapkan nasabnya maka ketetapan ini diterima apabila dia adalah seorang laki-laki yang mukallaf, adil, dan telah terbukti ketetapanya, (Sayyid Sabiq 2007: 169).

Dari uraian di atas dapat disimpulkan bahwa pengangkatan anak merupakan perbuatan yang terpuji dan dianjurkan oleh agama, memungut, mengasuh, memelihara, dan mendidik anak-anak yang terlantar demi kepentingan dan kemaslahatan anak dengan tidak memutuskan nasab orang tua kandungnya. Bahkan dalam keadaan tersebut di mana tidak ada orang lain yang memeliharanya, maka bagi orang yang mampu secara ekonomi dan pisikis yang menemukan anak terlantar tersebut hukumannya wajib tanpa harus memutuskan hubungan nasab dengan orang tua kandungnya dan anak tersebut diambil dan dipelihara seperti anak kandungnya sendiri.

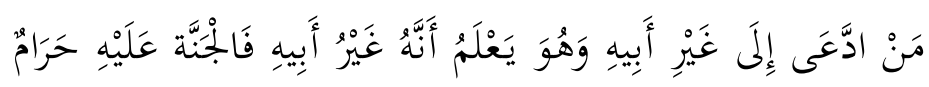


Tidak ada seseorangpun yang menasabkan dirinya kepada selain ayahnya padahal dia tahu dia bukan ayahnya kecuali dia telah kafir.” (HR. Bukhari dan Muslim).

Berdasarkan ayat dan hadits-hadits di atas maka hukum adopsi dengan menasabkan anak yang diadopsi oleh orang tua angkatnya adalah haram dalam Islam. Dan sebenarnya tidak ada hubungan apapun antara anak angkat dengan keluarga angkatnya, dan anak angkat itu harus dikasih tahu orang tua kandung yang sebenarnya kalau itu diketahui.

Dan berdasarkan uraian diatas juga dapat di simpulkan bahwa didalam KHI pemberian harta warisan kepada anak angkat menggunakan wasiat wajibah, didasarkan kepada pertimbangan kemanusiaan ahli waris untuk memberikan sebagian harta waris kepada anak angkat, meski secara syar'i hal tersebut termasuk zhanniy al-dilalah. Sehingga anak angkat mendapatkan harta warisan sebanyak $1 / 3$ dari harta waris dengan memakai wasiat wajibah.

\section{Kesimpulan}

Berdasarkan perspektif hukum Islam mengenai pengangkatan anak, bahwa pangangkatan anak tidak boleh memutus nasab antara si anak dengan orang tua kandungnya, hal ini kelak berkaitan dengan sistem waris dan perkawinan. Pemerintah telah mengakomodasi dan merespon terhadap permasalahan pengangkatan anak dengan mengeluarkan undang-undang perkawinan dan Kompilasi Hukum Islam untuk memenuhi kebutuhan masyarakat. Mengenai hak-hak anak angkat yang mesti dipenuhi menyangkut dengan tanggung jawab, pendidikan, dan kasih sayang menjadi konsekuensi orang tua angkat untuk memenuhi segala kebutuhan si anak. Dalam persoalan kewarisan, anak angkat tidak mendapatkan hak waris dari orang tua angkat, namun orang tua angkat boleh memberikan wasiat tidak lebih dari sepertiga (1/3) harta yang ditinggalkan. 


\section{DAFTAR PUSTAKA}

Alimudin, 2015. Praktek pengangkatan anak, Skripsi: Universitas. Negeri Raden Fatah, Palembang

Habiburrahman, 2011. Rekonstruksi Hukum Kewarisan Islam Di Indonesia. Jakarta, Prenada Media group.

Kamil, dan M.Fauzan, Ahmad, 2010. Hukum Perlindungan dan Pengangkatan Anak di Indonesia, Jakarta; PT RajaGrafindo Persada .

Mulyadi, Lilik. 2006. Pergeseran Perspektif dan Praktif dari Mahkamah Agung Mengenai Putusan Pemidanaan. Majalah Hukum Varia Peradilan Edisi No. 246 Mei 2006, Ikahi, Jakarta.

Prinst, Darwan. 2003. Hukum anak Indonesia, Bandung: PT Citra Aditya Bakti.

Pandika, Rusli. 2012.Hukum Pengangkatan Anak. Jakarta: Sinar Grafika.

Sayyid Sabiq, Muhammad. 2007. Fiqh Sunnah. Jakarta:Pena Pundi Aksara.

Zaini, Muderis. 1992. Adopsi suatu Tinjauan Dari Tiga Sistem Hukum, Jakarta: Sinar grafika. 